\title{
Mapping and conservation importance rating of the South African coastal vegetation as an aid to development planning
}

\author{
P.A. Raal ${ }^{*}$, M.E.R. Burns \\ Division of Earth, Marine and Amospheric Science and Technology, CSIR, P.O. Box 320. Stellenbosch, South Africa
}

\begin{abstract}
In 1989, the opportunity was identificd to create a botanical map series which could be used by authorities to make informed decisions and which would highlight the potential impact significance of proposed coastal developments on affected plant community types. In the past, vegetation impact assessments were conducted on a site specific basis and usually included community descriptions and species lists, which contributed little towards objective decision making. Impact significance at a broader, more meaningful spatial scale, for example biogeographical regions, was rarely established.

Based on the needs and the recognised problems, the CSIR developed a protocol for coastal vegetation mapping which included the following:

1. Simplification of the phytosociological complexity by recognising community types rather than communities as the phytosociological units;

2. Development of simple algorithm to determine a relative conservation importance hierarchy for the community types. Variables which are considered to be important for determining conservation importance are used in the algorithm;

3. Creation of a standard colour code to represent relative botanical importance for easy interpretation by non-experts;

4. Division of an approximately $1 \mathrm{~km}$ wide strip of the South African coastline into biogeographical regions so that botanical importance could be established initially at an ecologically meaningful spatial scale;

5. The use of recent, 1:10000 colour aerial photography as a baseline for all mapping and the standardisation of the mapping scale at 1:10000, based on the orthophoto map series, which is a recognised planning scale and which is adequate to identify and map community types;

6. The use of a Geographic Information System to capture and store the vegetation data and to produce high quality maps.

The benefits of the vegetation maps are that better decisions can be made with respect to the assessment of the significance of potential development impacts on coastal vegetation. Also, where vegetation importance is a key issue, this is recognised early in the decision making process. The strategy used to express relative botanical conservation importance has greatly facilitated the capability to perform objective first level assessments of potential development impact significance on coastal vegetation.
\end{abstract}

Keywords: Mapping; Conservation; Vegetation; Coast; South Africa; Development

\section{Introduction}

"Corresponding author.

The South African coastal zone is experiencing intense developmental pressure, primarily as a result

Elsevier Science B.V.

SSDI 0169-2046(95)00231-6 
of urban development, agriculture and mining (Sowman, 1990). The development record in South Africa also indicates that few environmental considerations have been effectively accommodated into coastal land-use planning (Sowman, 1990; Retief et al., 1991). As a result of development impacts, the extent of natural plant communities and habitats have decreased. Halting this trend is the challenge which currently faces South Africans, particularly, the authorities tasked with development planning and decision-making. The achievement of a balance between sustainable development and the retention of representative natural coastal ecosystems is a common goal of most stakeholders in the coastal zone.

Assessments of development impacts on vegetation, where such assessments are carried out, tend to be conducted on a site specific basis and usually include community descriptions and species lists. This information contributes little towards objective decision making. The impacts of developments at broader, more meaningful spatial scales, for example in terms of the phytogeographical spatial scale, have rarely been adequately assessed.

Huntley (1978) identified the need for the identification and representation of ecosystems on the basis of a national plan as a priority for developing longterm conservation strategies. By considering coastal vegetation types on a national scale, for example, the concept of habitat conservation is projected whereby ecosystems and not individual species, can be the focus of planning strategy.

The urgent need for an inventory of the extent and state of South Africa's diverse coastal resources, particularly the coastal vegetation, has been identified by Provincial planning authorities. It is recognised that the purpose of such an inventory should be to improve the quality of planning and decision-making in order to achieve the balanced sustainable development and conservation ideal. Maps are recognised as a good inventory medium for information capture and transfer (Cendrero, 1989).

The mapping efforts by Acocks (1953) and Moll et al. (1984), which provide vegetation coverage of South Africa and the Fynbos Biome respectively, provide good baseline information, but not at an appropriate scale for effective use by planners. The maps also do not provide an indication of the botanical importance of the mapped vegetation.

The CSIR was commissioned in 1989 by the Cape and Kwazulu/Natal Provincial Authorities to create

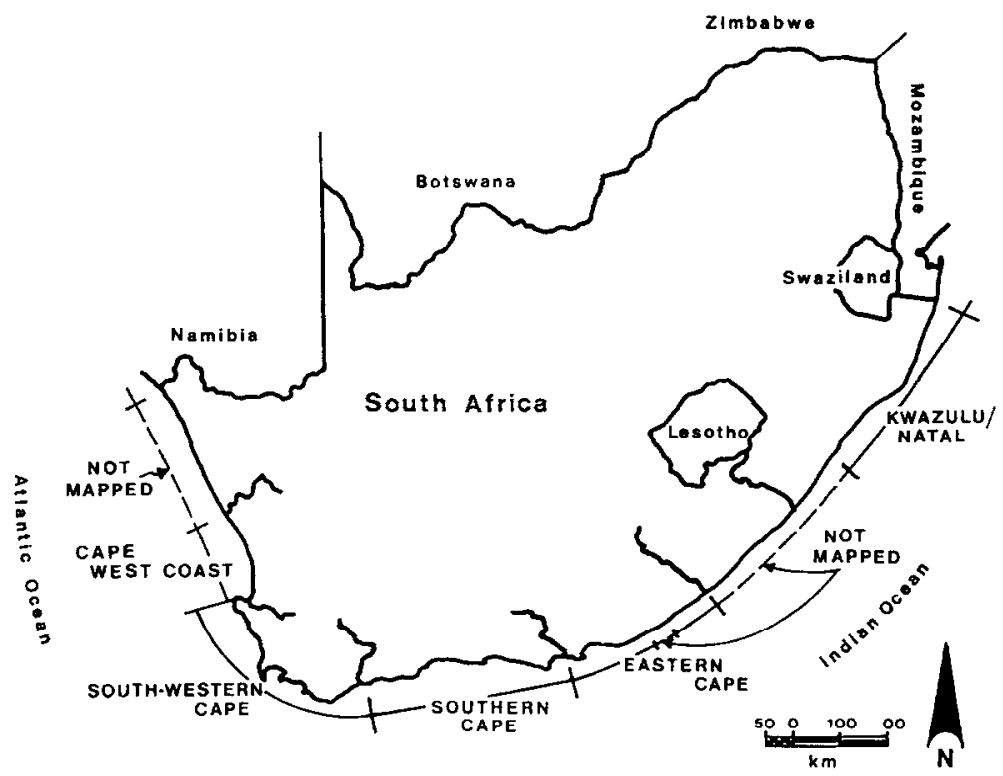

Fig. 1. Map showing the mapping sub-regions which co-incide with the local authority administrative boundaries. Areas which have not yet been mapped are also shown. 
a botanical map series which can be used by authorities to make informed decisions and which highlight the potential impact significance of proposed coastal developments on plant community types. The aim of the maps is to indicate the distribution of coastal vegetation in an easily interpretable manner and at an appropriate planning scale so that variation in botanical importance can be easily recognised by decision-makers and other interest groups. The information is intended to be used during the initial stages of development planning.

The objectives of the CSIR study were:

1. To delimit, describe and map the South African coastal vegetation within a zone extending approximately $1 \mathrm{~km}$ inland of the high water mark - community types and other major land-use categories were to be defined for mapping;

2. To provide an indication of the relative botanical importance of the mapped vegetation;

3. To capture the information in a format that facilitates continued updating and revision as more information becomes available; and

4. To create an end-product with a high visual impact that can be easily interpreted.

This paper describes the approach used by the CSIR to map the vegetation and to assign relative conservation importance values to the variety of recognised plant community types.

\section{Study area}

The study area which was included in the mapping exercise extends along approximately $3000 \mathrm{~km}$ of coastline between the Mozambique border on the east coast of South Africa to the Olifants River mouth on the west coast of the country (Fig. 1). The landward mapping boundary extends approximately $1 \mathrm{~km}$ inland from the coast but in certain areas extends considerably further into the coastal hinterland, particularly up some of the larger estuaries. Coastal stretches which have not yet been mapped within the greater study area are indicated in Fig. 1.

The study area is divided into mapping sub-regions which reflect the approximate phytogeographical variation along the South African coastline. The five sub-regions include the Kwazulu/Natal coast; the eastern Cape; the southern Cape; the south-western Cape; and the Cape west coast. The boundaries used to differentiate the sub-regions shown in Fig. 1 coincide with convenient local authority administrative boundaries.

The broad scale phytogeographical patterns of vegetation distribution tend to reflect the climatic and geomorphological gradients and transitions which are established along the coast (Heydorn and Tinley, 1980; Tinley, 1985). Within sub-regions, the nature of the substratum and topography are important environmental determinants of smaller scale patterns of vegetation distribution and the richness and diversity of species.

\subsection{Kwazulu / Natal}

The Kwazulu/Natal coast experiences a moist, sub-tropical climate with a summer rainfall pattern (approximately $1500 \mathrm{~mm}$ ) and a mean annual temperature above $20^{\circ} \mathrm{C}$. Deep red sediments and noncalcareous, unconsolidated aeolian sediments characterise the coastal dunes of this sub-region. Lakes and wetland communities are features of the southern Mozambique Plain which extends into the sub-region.

\subsection{Eastern Cape}

The Eastern Cape coast between the Great Kei and the Gamtoos river mouths is a transition zone between the sub-tropical summer rainfall region (approximately $800 \mathrm{~mm}$ per annum) in the east and the temperate winter rainfall region (between 500 and $800 \mathrm{~mm}$ ) in the west. The shift from a summer rainfall pattern north of the Kei River through bimodal and winter rainfall maxima, along the East London/Port Elizabeth and Cape St Francis coastlines respectively, towards an all year rainfall distribution pattern (approximately $600 \mathrm{~mm}$ per annum) in the west is marked determinant of vegetation type in this sub-region.

In addition to climate, the vegetation patterns within the sub-region are also controlled by the nature of the soils, which are derived from sandstone and dolerite intrusions, and the calcareous dune sedi- 
ments of the recent and more ancient coastal dune cordons.

\subsection{Southern Cape}

The coastline between the Gamtoos River and Cape Aghulas, which forms the southernmost tip of the African continent, experiences a temperate climate with a predominantly winter rainfall pattern (between $400 \mathrm{~mm}$ and $700 \mathrm{~mm}$ per annum). Coastline orientation and foreland topographic relief influence the rainfall pattern in the sub-region, particularly with respect to orographic control on precipitation.

The physical features of the coastline include remnant ancient dunes and recent dune formations. The dunes have a high calcium content apart from in high rainfall areas where leaching has resulted in decalcification. Limestone and sandstone formations characterise the surface geology. Stretches of steep, cliffed coastal forelands, for example along the Tsitsikamma coast, and barrier dune systems and associated lakes, for example along the Wilderness coastline, are striking features of the sub-region.

\subsection{South-western Cape}

The coastline between Cape Town and Cape Agulhas experiences a warm temperate climate (between $450 \mathrm{~mm}$ and $650 \mathrm{~mm}$ per annum) but between Cape Agulhas and the Breë River the climate is somewhat more arid (less than $450 \mathrm{~mm}$ per annum). Both areas experience a winter rainfall pattern and a hot, dry summer period.

A characteristic feature of this coastline in the east is the occurrence of calcrete ridges, outcrops and plates overlying sandstone. In the west, mountains composed of sandstone and shale extend to the sea and form steep coastal forelands.

The dune systems are rich in calcium and are comprised either of remnant ancient dunes or younger dunes created inter alia from reworked ancient sediments. At places along this coast a high marine terrace of truncated dunes is evident. Extensive wetland systems occur in areas where the coastal plain is well developed and are unique features of this stretch of coast.

\subsection{Cape west coast}

The West Coast experiences a Mediterranean climate with rain falling mainly in the cooler winter months with a summer drought period. There is a clear trend in the decrease in annual precipitation from approximately $180 \mathrm{~mm}$ at the Berg River to 60 $\mathrm{mm}$ at Port Nolloth in the north (Fig. 1).

The general topography includes a low-lying coastal plain which extends between the inland mountains and the Atlantic Ocean. The surface of the coastal plain is broken by sporadic outcrops of calcrete, granite and shale. The coastline is interrupted by extensive rocky stretches and headlands which are interspersed with curvilinear sandy beaches.

The coastal foreland which supports the vegetation along the West Coast, is characterised by thick accumulations of marine and aeolian sediments. The soils are generally calcareous in nature but tend to become decalcified and ferruginised with time.

\section{Methods}

\subsection{Aerial photograph interpretation}

Colour aerial photography prints, taken between 1987 and 1992 and produced at a scale of 1:10000, were used to stratify the vegetation into various units which could be recognised and mapped at the scale of the photography. Desk-top tracings on transparency overlays were used during the initial stratification exercise.

The potential and limitations of air photo interpretation for vegetation mapping are discussed in the literature (Edwards, 1972; Weisser, 1979; Jarman et al., 1983; and Westfall and Malan, 1986). In this exercise few problems were experienced with the interpretation and the general problem associated with image warping could be addressed effectively through comparison with the South African 1:10000 orthophoto series.

The community type, for example Dune Forest, was used as the mapping unit standard. Whittaker (1978) recognises that similar communities, grouped together represent a community type, which is a class concept. A community type is, however, to be clearly distinguished from the plant communities in 
the field, the classification of which fell beyond the scope of this study.

Community types were identified principally on the basis of colour and structural variation evident on the photographs.

Ground truthing of the vegetation and other landuse units was carried out systematically between 1989 and 1993, during which the general phytosociology, extent of infestation by invasive alien plants and the condition of the community types over their distribution ranges were assessed. Spot values were used on the draft map overlays to indicate the extent of alien infestation and degree of impact observed at as many locations as possible. During ground truthing, adjustments were made where necessary to the boundaries of the community types that were identified during the desk-top study.

The boundary delineation of the community types recognised along much of the coastline is based largely on the interpretation of aerial photographs and the observations made during field inspections. Where appropriate, some extrapolation was made based on the results of published phytosociological studies which have been adapted to the more coarse level of classification used during this mapping exercise.

The refined boundaries of the community types were adjusted on the overlays and corrected to a common scale of $1: 10000$, based on the orthophoto maps.

Table 1

Variables used in the importance classification of the vegetation including the quantitative values assigned to each category

\begin{tabular}{|c|c|c|}
\hline \multicolumn{2}{|c|}{ Variables used in the importance analysis } & $\begin{array}{l}\text { Quantitative value } \\
\begin{array}{l}1=>1000 \text { ha cover } \\
2=100-1000 \text { ha } \\
3=0-100 \text { ha }\end{array}\end{array}$ \\
\hline Endemism & $\begin{array}{l}\text { The number of nationally endemic species within each recognised commu- } \\
\text { nity type expressed relative to the total number of endemic species for the } \\
\text { sub-region. }\end{array}$ & $\begin{array}{l}1=0-10 \% \text { endemics } \\
2=10-20 \% \\
3=20-30 \% \\
4=30-40 \% \\
5=>40 \%\end{array}$ \\
\hline Species richness & $\begin{array}{l}\text { The estimated species richness within each community type determined } \\
\text { from the literature and field observations expressed relative to the total } \\
\text { number of species estimated to occur within the sub region. }\end{array}$ & $\begin{array}{l}1=0-5 \% \\
2=5-10 \% \\
3=10-15 \% \\
4=15-20 \% \\
5=>20 \%\end{array}$ \\
\hline Invasive alien plants & $\begin{array}{l}\text { Extent to which each community type is impacted by alien vegetation } \\
\text { determined from field observations and expressed as mean percentage } \\
\text { infestation. }\end{array}$ & $\begin{array}{l}1=>20 \% \\
2=10-20 \% \\
3=5-10 \% \\
4=1-5 \% \\
5=0-1 \%\end{array}$ \\
\hline Disturbance & $\begin{array}{l}\text { Extent to which each community type has been disturbed by land-use } \\
\text { activities determined from field observations and expressed as a percentage } \\
\text { disturbance value. }\end{array}$ & $\begin{array}{l}1=>20 \% \text { abuse } \\
2=10-20 \% \\
3=5-10 \% \\
4=1-5 \% \\
5=0-1 \%\end{array}$ \\
\hline
\end{tabular}




\subsection{Geographical information system data capture and map production}

The boundaries of the mapped community types were digitised using the Arc/Info Geographic Information System (GIS). The attribute information attached to each polygon in the course of the digitising process included the identity of the community types contained within the polygon boundaries. The relative botanical importance value or second polygon attribute, was assigned to the polygons during a subsequent data enhancement exercise once the importance analysis had been completed.

The spot values indicating percentage infestation of the vegetation by invasive alien plants and percentage of area disturbed at the various inspected sites at the time of the survey were also captured by the GIS.

\subsection{Importance analysis of the community types}

In order to enhance the value of the mapping data for planning, primarily with respect to establishing the potential impact of development on the vegetation, an integrated classification process was applied to the data for each sub-region. Variables used to classify the community types in order to establish a botanical importance hierarchy within the sub-regions, include the relative abundance of the community types, species richness, and the apparent degree of impact or disturbance to the vegetation. These variables include those that are most widely used in such exercises (Jarman, 1986).

The data used in the importance classification of the vegetation include both quantitative values, such as the extent or coverage of the community types, which could be established from the GIS, and qualitative information derived from the field observations and from published and unpublished sources (Table 1). The paucity of information on species richness and the presence of threatened and endemic species required a qualitative or more subjective approach towards quantifying these variables.

Using the above data an integrated importance value was determined for each community type using a simple arithmetic formula (see below). The formula provides a method to facilitate consistent ranking of all the community types within each sub-region.

Weighted arithmetic formula used to determine the conservation importance values for the community types within each sub-region.

$$
\begin{aligned}
& \text { Numerical Importance Value } \\
& =[\text { Vegetation Type Rarity Factor } \\
& \times \text { Level of Endemism + Species * Richness } \\
& + \text { Threatened Species }+\frac{\text { Disturbance }}{2} \\
& \left.+\frac{\text { Alien Veg }}{2}\right] \\
& * \text { Value; See Table } 1 .
\end{aligned}
$$

The numerical importance values obtained for each sub-region are relative; the higher the vegetation score, the higher its relative botanical conservation importance.

Primary community types, which exhibit few signs of major unnatural disturbance, are scored as either being of high or intermediate botanical conservation importance. Secondary community types, which have developed in response to significant unnatural disturbance, are considered to be of relatively low conservation importance.

All alien plant communities, artificially established vegetation and non-vegetation areas are considered to have an insignificant botanical conservation importance.

Community types of high importance are considered to be those which have one or more of the following characteristics: they are comparatively rare; they include several threatened or endemic species; and are species-rich. Rarity may be a function of past development impact and the priority for conserving particular community types may therefore be based on the degree of development threat already imposed on them as well as their ecological value or importance.

\subsection{Vegetation maps}

Using the GIS data, 1:10000 maps were prepared as transparent overlays. A colour code is used on the maps to indicate the different botanical conservation 
importance categories where: purple is high; red and orange are intermediate; brown is low; and green is insignificant botanical conservation importance. The community types falling within each category are allocated a hatching pattern based on their assigned importance value where dense hatching represents the more important community types.

In addition to the hard copies, the maps can also be viewed as computer graphics using ARCVIEW which is a utility software for Arc/Info. The maps are easily updated and revised conservation importance analyses are easily performed using the GIS software.

\section{Results}

The major community types which occur within the recognised phytogeographical regions are described below. A summary of the community types occurring within each sub-region is presented in Appendix A.

\section{Kwazulu / Natal}

The vegetation of the Kwazulu/Natal north coast is diverse, comprising numerous community types. Most of the area is covered by either Climax Dune Forest, a mosaic of Dune Forest or Syzigium cordatum Woodland and Secondary Grassland or Dwarf Shrubland, with the remainder being made up of wetland community types, plantations, cultivated lands or developed areas. The most important community type in the study area is the Cirque vegetation which is extremely rare and which develops on the seaward slopes of the dune cordon north of Richards Bay following natural slumping. Other community types considered to be of high conservation priority include Saltmarsh; Mangroves; Swamp Forest; and unique mosaics of diverse community types.

Because of their relatively wide distribution, Climax Dune Forest and the mosaic of Dune Forest and Secondary Grassland or Dwarf Shrubland are considered to be of intermediate conservation importance.

\section{Eastern Cape}

The Eastern Cape coastline is characterised by a variable climate and diverse topographic and geological patterns. This edaphic diversity has allowed the Cape, Afromontane, Tongaland-Pondoland and $\mathrm{Ka}$ roo-Namib plant phytochoria to converge and form a highly complex vegetation structure. A changing rainfall pattern is considered to be the most important factor affecting the distribution of the vegetation in this sub-region, although geological and soil variations also play a major role.

The most important community type in the Eastern Cape is Succulent Transitional Thicket. Other community types considered to be of high conservation priority include Afromontane Forest; Coastal Grassland; Vleis; and Halophytic Rocky Coast Communities.

Xeric Transitional Thicket; Forest and Thicket on Ancient Dunes; Dune Forest and Thicket and Stunted Dune Thicket; Saltmarsh; and Dune Fynbos have relatively wide distribution patterns and are considered to be of intermediate conservation priority.

Secondary Grassland and Acacia karoo Savanna are the most common secondary community types in this sub-region.

\section{Southern Cape}

Highly variable rainfall, topographic and soil patterns have resulted in a complex vegetation structure along the southern Cape coastline. The Cape flora is well represented and many different Fynbos community types are recognised. The most important vegetation in this sub-region is the mosaic of Xeric Transitional Thicket and Limestone Fynbos. Other community types considered to be of high conservation importance include the mosaic of Afromontane Forest and Mesic Mountain Fynbos; Renosterveld; Succulent Transitional Thicket; Halophytic Rocky Coast Communities; and Dune Forest and Thicket and Stunted Dune Thicket.

Mountain Fynbos; Limestone Fynbos; Mosaics of Fynbos and Dune Thicket on Ancient Dunes; Coastal Grassland; Afromontane Forest; Xeric Transitional 
Thicket; Dune Fynbos; Fynbos and Dune Thicket Mosaic; Forest and Thicket on Ancient Dunes; Saltmarsh; and Vleis are considered to be of intermediate conservation importance.

Secondary Grasslands and mosaics of Dune Fynbos and Agriculture or Alien Vegetation are the most common secondary community types in the Southern Cape sub-region.

\section{South-western Cape}

The vegetation in this sub-region clearly reflects the controls of the climatic environment. The sclerophyllous nature of the Fynbos elements and the abundance of succulent species are obvious adaptations that allow communities to function effectively under Mediterranean climatic conditions.

The most important community type in this subregion is Afromontane Forest. Other community types considered to be of high conservation importance include Halophytic Rocky Coast Communities; Xeric Transitional Thicket; Renosterveld; BerzeliaOsmitopsis Seepage Fynbos; Maurocenia Thickets; Chondropetalum Seeps; Dune Forest and Thicket and Stunted Dune Thicket; Limestone Fynbos; Restionaceous Plateau Fynbos; Limestone Shrubland; West Coast Strandveld; and Saltmarsh.

Mountain Fynbos; Vleis; Granite Shrubland; Restionaceous Tussock Marsh; Scree Fynbos; Arid Succulent Dune Shrubland; West Coast Strandveld and Grassland Mosaic; Dune Fynbos; Dune Slack and Strand Vegetation; Saltmarsh and Reedswamp Mosaic; and Dune Fynbos and Thicket Mosaic are considered to be of intermediate conservation priority. The most common secondary community types are Wildenowia Veld and Secondary Grassland.

\section{Cape west coast}

The abundance of succulent species clearly reflects the aridity of the area and the obvious adaptation of the vegetation to function effectively under stressed environmental conditions. Survival strategies of the perennial species are highly specialised under the semi-desert conditions that are characteristic of this coastline.
The most important community type in the study area is Arid Succulent Granite Shrubland. Other community types considered to be of high conservation priority include Sandstone Shrubland; the Mosaic of Stunted Dune Thicket and Arid, Tall Succulent Dune Shrubland; Arid, Tall Succulent Dune Shrubland; Dune Forest and Thicket and Stunted Dune Thicket; and Terra rossa Strandveld.

Chondropetalum Seeps; Strand Vegetation; Slack Herb- and Shrubland; Mosaic of Saltmarsh and Vlei; Vleis; Succulent Karoo Shrubland; Primary West Coast Dune Shrubland; West Coast Strandveld; Saltmarsh; and Arid West Coast Shrubland are considered to be of intermediate conservation priority.

Secondary community types include Wildenowia Veld; Secondary Grassland; and Artificially Established Dune Shrubland.

\section{Discussion}

The evaluation of coastal areas for planning and land-use management requires a detailed knowledge of the land which may be affected. This knowledge must be presented in such a way that it can be easily interpreted and incorporated by planners and decision-makers. An effective way to summarise and present this kind of knowledge is through the use of appropriate maps.

With the specific aim of defining levels of conservation importance for the coastal vegetation along the South African coastline, an analytical approach was followed to produce a series of vegetation/conservation importance maps, at a 1:10000 scale for use with the orthophoto map series. The maps depict the community types and their associated conservation importance rating using a combination of colour and hatching patterns and present, in terms of vegetation as one planning variable, the suitability of the landscape for development, for example. The map data is stored on a structured Geographic Information System for ease of manipulation, fast access and to enable greater flexibility in their use and ease of up-dating.

The level of mapping and the representation and assessment of the vegetation was done at the sub-regional level in a form which is coherent with the current purpose and level of planning in South Africa. 
The representation of the coastal vegetation by means of a series of interpretative maps provides rapid insight into the distribution of the different community types within each sub-region and the identification of areas of high, intermediate, low or insignificant botanical conservation importance.

The study has shown that the majority of coastal community types have been degraded to some degree. In order to prevent the further degradation of pristine natural vegetation, all future developments will need to be planned taking botanical conservation importance into consideration. The vegetation maps clearly indicate which community types should ideally be zoned for preservation and which can be considered for various kinds of development.

The aim of the maps, which should be used during all stages of development planning within the coastal zone, is to direct most future development towards botanically low priority areas which have no other constraints for development. It is anticipated that land-use planners will use the maps in such a way so as to maintain the highest degree of botanical diversity while still meeting planning objectives.

The most seriously threatened community types are those which occur in areas of rapid development. It is clear from this study that, unless sufficiently large examples of the affected ecosystems are protected within the next few years, their chances of long-term survival are remote.

Although less critical, the status of many community types of intermediate conservation importance is also insecure.

The mapping approach which has been used is a novel approach which only provides a first level of quantitative, objective assessment of the conservation importance status of major community types along the South African coastline on a sub-regional, regional and national scale. It is not intended to be a rigid classification but is specifically designed to make future refinements easy to undertake.

\section{Appendix A}

Summary of the community types and other landuse units found in each of the five sub-regions
(Figure 1), and the conservation importance category within which they occur.
A.l. Kwazulu / natal

HIGH CONSERVATION IMPORTANCE

Cirque Communities

Mosaic of Dwarf Shrubland and Hyphaene Palmland

Saltmarsh

Swamp Forest

Mosaic of Primary Reedswamp and Climax Dune Forest

Mangroves

Mosaic of Sedgeland and Primary Reedswamp

Mosaic of Encephalartos ferox Veld and Dwarf Shrubland

INTERMEDIATE CONSERVATION IMPORTANCE

Mosaic of Primary Reedswamp and Swamp Forest

Climax Dune Forest

Primary Dune Shrubland

Vlei/Sedgelands

Dune Slack and Strand Vegetation

Primary Reedswamp

LOW BOTANICAL CONSERVATION IMPORTANCE

Mosaic of Climax Dune Forest and Dwarf Shrubland Mosaic of Climax Dune Forest and Secondary Grassland

Mosaic of Syzigium cordatum Woodland and Dwarf Shrubland

Dwarf Shrubland

Hygrophilous Grassland

Mosaic of Hygrophilous Grassland and Dwarf Shrubland

Secondary Dune Shrubland and Thicket

Secondary Grassland

Mosaic of Acacia karroo Woodland and Dwarf Shrubland

Acacia karroo Woodland

Secondary Reedswamp 
INSIGNIFICANT BOTANICAL CONSERVATION IMPORTANCE

\section{Dense Alien Communities}

Development

Open Sandy Areas

Plantations and Woodlots

Agricultural Lands

Mosaics of Secondary Grassland and Plantations

\section{A.2. Eastern cape}

\section{HIGH CONSERVATION IMPORTANCE}

Succulent Transitional Thicket

Afromontane Forest Communities

Coastal Grassland

Vleis

Halophytic Rocky Coast Communities

\section{INTERMEDIATE CONSERVATION IMPOR- TANCE}

Xeric Transitional Thicket

Forest and Thicket on Ancient Dunes

Dune Forest and Thicket and Stunted Dune Thicket Saltmarsh (undifferentiated)

Fynbos and Dune Thicket Mosaic

Dune Fynbos

LOW BOTANICAL CONSERVATION IMPORTANCE

Dune Slack and Strand Vegetation

Secondary Grassland

Mosaic of Natural Vegetation and Agriculture

Acacia karoo Savanna

INSIGNIFICANT BOTANICAL CONSERVATION IMPORTANCE

Developed Areas

Alien Vegetation

Cultivated lands and Plantations

Open Sandy Areas

\section{A.3. Southern cape}

\section{HIGH CONSERVATION IMPORTANCE}

Mosaic of Xeric Transitional Thicket and Limestone Fynbos

Mosaic of Afromontane Forest and Mesic Mountain Fynbos

Renosterveld

Succulent Transitional Thicket

Halophytic Rocky Coast Communities

Dune Forest and Thicket and Stunted Dune Thicket

INTERMEDIATE CONSERVATION IMPORTANCE

Mountain Fynbos

Limestone Fynbos

Mosaics of Fynbos and Dune Thicket on Ancient

Dunes

Coastal Grassland

Afromontane Forest Communities

Xeric Transitional Thicket

Dune Fynbos

Fynbos and Dune Thicket Mosaic

Forest and Thicket on Ancient Dunes

Saltmarsh (Undifferentiated)

Vleis

LOW BOTANICAL CONSERVATION IMPORTANCE

Dune Slack and Strand Vegetation

Secondary Grassland

Mosaics of Dune Fynbos and Agriculture

Mosaics of Dune Fynbos and Dense Alien Vegetation

Artificially Established Dune Shrubland

INSIGNIFICANT BOTANICAL CONSERVATION IMPORTANCE
Alien Vegetation
Developed Areas
Cultivated Lands and Plantations
Open Sandy Areas 


\section{A.4. South-western cape}

\section{HIGH CONSERVATION IMPORTANCE}

Afromontane Forest Communities

Halophytic Rocky Coast Communities

Xeric Transitional Thicket

Renosterveld

Berzelia-Osmitopsis Seepage Fynbos

Maurocenia Thickets

Chondropetalum Seeps

Dune Forest and Thicket and Stunted Dune Thicket

Forest and Thicket on Ancient Dunes

Limestone Fynbos

Restionaceous Plateau Fynbos

Limestone Shrublands

West Coast Strandveld

Saltmarsh (Undifferentiated)

\section{INTERMEDIATE CONSERVATION IMPOR-} TANCE

Mountain fynbos

Vleis

Granite Shrublands

Restionaceous Tussock Marsh

Scree Fynbos

Arid Succulent Dune Shrublands

West Coast Strandveld and Grassland Mosaic

Dune Fynbos

Dune Slack and Strand Vegetation

Mosaic of Saltmarsh and Primary Reedswamp

Fynbos and Dune Thicket Mosaic

Dune Slack and Strand Vegetation

LOW BOTANICAL CONSERVATION IMPORTANCE

Wildenowia Veld

Secondary Grassland

Mosaic of Dense Alien Vegetation and Dune Fynbos Mosaic of Agriculture and Dune Fynbos

Artificially Established Dune Shrubland

INSIGNIFICANT BOTANICAL CONSERVATION IMPORTANCE
Developed Areas

Alien Vegetation

Cultivated Lands and Plantations

Open Sandy Areas

Mosaics of Alien Vegetation and Secondary Grassland

\section{A.5. Cape west coast}

\section{HIGH CONSERVATION IMPORTANCE}

Arid Succulent Conglomerate Shrubland

Sandstone Shrubland

Mosaic of Stunted Dune Thicket and Arid, Tall

Succulent

Dune Shrubland

Arid, Tall Succulent Dune Shrubland

Dune Forest and Thicket and Stunted Dune Thicket Terra Rossa Strandveld

INTERMEDIATE CONSERVATION IMPORTANCE

Chondropetalum Seeps

Strand Vegetation

Slack Herb- and Shrubland

Mosaic of Saltmarsh and Vlei

Vleis

Succulent Karoo Shrubland

Primary West Coast Dune Shrubland

West Coast Strandveld

Saltmarsh (Undifferentiated)

Arid West Coast Shrubland

LOW BOTANICAL CONSERVATION IMPORTANCE

Wildenowia Veld

Secondary Grassland

Artificially Established Dune Shrubland

INSIGNIFICANT BOTANICAL CONSERVATION IMPORTANCE

Pans

Developed Areas 


\section{Alien Vegetation \\ Cultivated lands \\ Open Sandy Areas}

\section{References}

Acocks, J.P.H., 1953. Veld types of South Africa. Mem. Bot. Surv. S. Afr., 28: 1-128.

Cendrero, A., 1989. Mapping and evaluation of coastal areas for planning. Ocean and Shoreline Manage., 12: 427-462.

Edwards, D., 1972. Remote sensing in the evaluation of the natural vegetation resources of South Africa. Proc. 5th Symp. Remote Sensing, Pretoria, CSIR, May 1972: 99-102.

Heydorn, A.E.F. and Tinley, K.L., 1980. Estuaries of the Cape. Part 1. Synopsis of the Cape coast. Natural features, dynamics and utilisation. Stellenbosch: CSIR Research Report 380, 96 pp.

Huntley, B.J., 1978. Ecosystem conservation in Southern Africa. In: Werger, M.J.A. (Editor), Bibliogeography and Ecology of Southern Africa. Junk, The Hague.

Jarman, M.L., 1986. (Editor) Conservation priorities in the lowland regions of the Fynbos biome. Pretoria: South Afr. Natl. Sci. Programmes Rep. 87, 55 pp.
Jarman, M.L., Jarman, N.G. and Edwards, D., 1983. Remote sensing and vegetation mapping in South Africa. Bothalia, 14 (2): $271-282$.

Moll, E.J., Campbell, B.M., Cowling, R.M., Bossi, L., Jarman, M.L. and Boucher, C., 1984. A description of the vegetation categories in and adjacent to the Fynbos biome. Pretoria: South Afr. Natl. Sci. Programmes Rep. 83, 29 pp.

Retief, D., Coetzee, M., Little, T. and Olen, B., 1991. Coastal Zone '91. Proceedings of the 10th Symposium on Coastal and Ocean Management, ASCE, New York, pp. 2750-2762.

Sowman, M.R., 1990. Environmental evaluation procedure for coastal developments in South Africa. Ocean and Shoreline Manage., 14: 133-150.

Tinley, K.L., 1985. Coastal dunes of South Africa. Pretoria: South Afr. Natl. Sci. Programmes Rep. 109, 300 pp.

Weisser, P.J., 1979. Suitability of air photo interpretation for monitoring coastal dune vegetation of the Zululand dunes, South Africa. In: The use of ecological variables in environmental monitoring. The National Swedish Environmental Protection Board, Report PM 1151: 62-72.

Westfall, R.H. and Malan, O.G., 1986. A method for vegetation stratification using scale-related vegetation-enhanced satellite imagery. Bothalia, 16 (2): 262-268.

Whittaker, R.H. (Editor), 1978. Classification of plant communities. Junk, The Hague. 